\title{
Effects of chromium supplementation on growth, nutrient digestibility and meat quality of growing pigs
}

\author{
A. E. Untea\#, I. Varzaru, T. D. Panaite, M. Habeanu, M. Ropota, M. Olteanu \& G. M. \\ Cornescu
}

National Research and Development Institute for Biology and Animal Nutrition, Calea Bucuresti, No.1, 077015, Balotesti, llfov, Romania

(7 December 2016; Accepted 16 March 2017; First published online 10 April 2017)

\author{
Copyright resides with the authors in terms of the Creative Commons Attribution 4.0 South African Licence. \\ See: http://creativecommons.org/licenses/by/4.0/za \\ Condition of use: The user may copy, distribute, transmit and adapt the work, but must recognise the authors and the South African \\ Journal of Animal Science.
}

\begin{abstract}
The aim of the study was to evaluate the effects of chromium picolinate (CrPic) on growth performance, nutrient digestibility, and protein and lipid quality of five anatomical parts in growing pigs. The 30-day study was conducted on eight castrated Topigs growing male pigs, with an initial bodyweight of 17.16 $\pm 0.62 \mathrm{~kg}$. The pigs were assigned to two groups (C, E), housed in individual metabolic cages, and fed on conventional diets with $17.80 \%$ crude protein $(\mathrm{CP})$ and $3078 \mathrm{kcal} / \mathrm{kg}$ metabolizable energy (ME). The diet of $\mathrm{E}$ was supplemented with $200 \mathrm{ppm}$ CrPic. Samples of ingesta and faeces were collected in three balance periods of five days each. At the end of the experiment, blood samples were collected, all pigs were slaughtered, and meat (tenderloin, loin, ham, shoulder, and belly) samples were collected. No significant differences of productive or plasma parameters were noticed. The results of the balance study showed that CrPic did not influence the digestibility of nitrogen, but the digestibility of fat was significantly decreased for group E. The nutritional quality of the collected samples was evaluated for proximate analysis. The tenderloin and ham samples had increased protein concentrations compared with $\mathrm{C}$ group. For belly and ham, the fat concentrations decreased significantly. As a result of this observation, amino acids and fatty acid profiles were analysed and a significant improvement were determined for $\mathrm{E}$ regarding essential amino acids. The conclusion of the study was that $\mathrm{CrPic}$ had positive effects on protein and fat metabolism and the meat had functional food attributes.
\end{abstract}

Keywords: Amino acids, biochemical profile, chromium picolinate, digestibility, fatty acids, pork

"Corresponding author: arabela.untea@ibna.ro

\section{Introduction}

In the living organism, chromium $(\mathrm{Cr})$ is a component of glucose tolerance factor. Its primary role in metabolism is to enhance the glucose uptake by tissues (Pechova \& Pavlata, 2007). Chromium can also be supplemented to reduce the negative effects of environmental stress, dietary and hormonal stress (Sahin et al., 2002), and immune stress (Heugten \& Spears, 1997).

Chromium supplementation to diets for swine may improve specific growth and carcass responses (Jackson et al., 2009). It was noticed that the experimental period is a major factor that determines the pig's response to $\mathrm{Cr}$ supplementation (Amata, 2013). Several authors (Page et al., 1993; Lindemann et al., 1995: Mooney \& Cromwell, 1995) have reported variable results when the experiments were for the entire growingfinishing period. Sales \& Jancík (2011) designed a meta-analysis to describe the effects reported in several studies. According to random effects models, average daily gain, percentage carcass lean, longissimus muscle area increased, and 10th-rib fat thickness decreased under dietary $\mathrm{Cr}$ supplementation.

Chromium sources used in animal experiments were chromium picolinate (CrPic), chromium nicotinate, chromium chloride and less $\mathrm{Cr}$ propionate, but some authors consider that the organic source of $\mathrm{Cr}$ is over ten times more bioavailable than inorganic sources (Shelton et al., 2003).

There has been limited research on the effect of $\mathrm{Cr}$ supplementation on the nutritional quality of various anatomical parts (tenderloin, ham, shoulder, etc). Most published research refers to the longissimus muscle area and total carcass lean (Shelton et al., 2003), drip loss in chops (Wang \& Xu, 2004), loin pH, drip and purge loss (Matthews et al., 2005), backfat and the iodine value of belly (Jackson et al., 2009), carcass lean ratio and carcass fat ratio (Wang et al., 2014), and meat colour (Li et al., 2013). The concentrations of 
protein and fat are critical attributes of carcass quality (Monziols et al., 2006). Protein quality is described by its ability to provide specific concentrations and patterns of amino acids (Millward et al., 2008). Saturated and unsaturated fatty acids can provide information about the palatability and rancidity of fat (Hoffman et al., 2005).

The purpose of this study was therefore to determine the influence of supplementing $\mathrm{Cr}$ as picolinate on growth, plasma metabolites, nitrogen and fat digestibility, and pork quality (amino acids and fatty acid composition of various tissues) in growing pigs.

\section{Material and methods}

The experiment was performed in compliance with Directive 2010/63/EU on the protection of animals used for scientific purposes and all procedures were described. It was approved by the Ethical Commission of National Research and Development Institute for Biology and Animal Nutrition, Balotesti, Romania.

The experiment was conducted on eight growing castrated hybrid TOPIGS (Large White $x$ Hybrid (Large White $\times$ Pietrain) female) $\times$ Talent (mainly Duroc) male pigs, aged $57 \pm 3$ days, under conditions of experiment balance and it ran for 30 days. Throughout the experimental period, the piglets were randomly assigned to two groups (four animals per group), kept in individual metabolic cages (Agrico, Rybarska, Czech Republic) with an area of $0.87 \mathrm{~m}^{2}$, placed in an experimental hall under controlled environmental conditions (temperature of $24{ }^{\circ} \mathrm{C}$, humidity 50 to $60 \%$ ). The piglets were fed their diets daily at 8.00 a.m. ad libitum. The amount of feed given to each pig was weighed daily, as well as the leftovers (collected each morning). Water was supplied ad libitum via drinking nipples. The pigs had an average initial bodyweight of $17.16 \pm 0.6 \mathrm{~kg}$. They received a commercial diet designed for this category of animals, which differed between groups according to the level of $\mathrm{Cr}^{3+}$ supplement (Table 1). The source of $\mathrm{Cr}^{3+}$ was $\mathrm{Cr}$ picolinate (Sigma Aldrich, Germany). It brought the chromium level to $200 \mu \mathrm{g} \mathrm{Cr} / \mathrm{kg}$ feed in E group. The productive parameters (average daily gain, feed conversion) were calculated from the records of bodyweights and feed intake.

After five days for accommodation, the nutrient balance was determined during three periods of five days each. During the three periods of balance (5 days/week) samples of excreta (faeces) were collected daily from each animal and average weekly samples were formed. The faeces were collected once a day and stored at about $30^{\circ} \mathrm{C}$. At the end of the collection period, the faeces were weighed and homogenised. Faeces samples were dried at $65^{\circ} \mathrm{C}$ in stove BMT model Ecocell Blueline Comfort (Nuremberg, Germany) and ground with a Grindomix GM 200 mill (Retsch, Germany).

The coefficients of apparent absorption of nitrogen and fat were calculated using the data from the chemical analysis on the feeds and faeces, corroborated with the daily records of the intake and excreta, using digestibility equations proposed by Schiemann (1981).

Blood was collected in heparin tubes, centrifuged for 10 minutes at $2500 \mathrm{rpm}$. The resulting plasma samples were analysed for haematological and biochemical parameters.

At the end of the experiment, after blood sample collection, all pigs were slaughtered in an experimental abattoir. Five cuts (tenderloin, shoulder, loin, ham and belly) were dissected, deboned, external fat removed, frozen at $-80^{\circ} \mathrm{C}$ and kept until chemical analysis.

The CP of the diet, faeces and muscles was determined using a semiautomatic classical Kjeldahl method using a Tecator Kjeltek auto 1030 analyser (SR EN ISO 5983-2, 2009). The fat was extracted using an improved version of the classical method by continuous extraction in solvent, followed by fat measurement with Soxhlet after solvent removal (SR ISO 6492, 2001).

Gas chromatograph Perkin-Elmer Clarus 500 (Massachusetts, United States), fitted with a flame ionization detector (FID) and capillary separation column with high polar stationary phase TRACE TR-Fame, (Thermo Electron, Massachusetts, United States), dimensions $60 \mathrm{~m} \times 0.25 \mathrm{~mm} \times 0.25 \mu \mathrm{m}$, was used to determine the fatty acid composition of the meat samples. Each sample was prepared as described previously (Habeanu et al., 2011).

HPLC Surveyor Plus Thermo Electron, (Massachusetts, United States) and HyperSil BDS C18 column (Thermo Electron, Massachusetts, United States) dimensions $250 \mathrm{~mm}$ X $4.6 \mathrm{~mm}$ X $5 \mu \mathrm{m}$ were used to determine the amino acid profiles of the meat samples. Each sample was prepared as described previously (Varzaru et al., 2013).

Blood samples were collected from slaughtered pigs at the end of experiment. The blood samples were collected from the jugular vein in tubes with EDTA for hematologic determination (white blood cells (WBC) red blood cells (RBC); haemoglobin (HG); haematocrit (HCT), mean corpuscular haemoglobin $(\mathrm{MCH})$, mean corpuscular volume (MCV), mean corpuscular haemoglobin concentration (MCHC)) and biochemical determinations (total cholesterol and total protein) on a Mindray BC 2800 VET auto haematology analyser (China). 
Each pig was considered an experimental unit. All data are expressed as mean value \pm standard error of the mean (SEM). The analytical data were compared with analysis of variance (ANOVA), using STATVIEW for Windows (SAS, version 6.0). The differences between mean values in the groups were considered significant at $P<0.05$.

Table 1 Formulation and chemical composition of compound feeds used for hybrid Topigs piglets

\begin{tabular}{lcc}
\hline Ingredients (g/Kg as feed bases) & C & E (+ CrPic) \\
\hline Maize & 375.9 & 375.9 \\
Wheat & 260.0 & 260.0 \\
Rice bran & 90.0 & 90.0 \\
Soybean meal & 160.0 & 160.0 \\
Sunflower meal & 40.0 & 40.0 \\
Corn gluten & 30.0 & 30.0 \\
Calcium carbonate & 18.0 & 18.0 \\
Mono calcium phosphate & 9.0 & 9.0 \\
Salt & 2.0 & 2.0 \\
Methionine & 0.5 & 0.5 \\
Lysine & 3.6 & 3.6 \\
Choline & 1.0 & 1.0 \\
Premix & 10.0 & - \\
Premix* & - & 10.0 \\
Calculated nutrients ( $\mathrm{g} / \mathrm{kg}$ feed) & & \\
ME (Kcal / $\mathrm{kg}$ ) & 3078 & 3078 \\
Crude protein (g) & 178.0 & 178.0 \\
Crude fat (\%) & 33.9 & 33.9 \\
Crude fibre (\%) & 42.0 & 42.0 \\
Calcium (\%) & 9.0 & 9.0 \\
Phosphorus (\%) & 6.5 & 6.5 \\
\end{tabular}

ME-Metabolisable Energy, C-Control, E- Control + chromium picolinate, CrPic- chromium picolinate, *Ingredients per kilogram of diet: $6000 \mathrm{IU}$ of vitamin A, $1500 \mathrm{IU}$ of vitamin D3, $10 \mathrm{IU}$ of vitamin E, $1.5 \mathrm{mg}$ of vitamin K3, $1.0 \mathrm{mg}$ of vitamin $\mathrm{B} 1,3.0 \mathrm{mg}$ of vitamin B2, $10.0 \mathrm{mg}$ of d-pantothenic acid, $15.0 \mathrm{mg}$ of niacin, $1.0 \mathrm{mg}$ of vitamin B6, $15.0 \mathrm{~g}$ of vitamin B12, $250 \mathrm{mg}$ of FeSO $4 \times 7 \mathrm{H} 2 \mathrm{O}, 62.8 \mathrm{mg}$ of CuSO4, $197.4 \mathrm{mg} \mathrm{ZnSO} 4 \times 7 \mathrm{H} 2 \mathrm{O}, 38.8 \mathrm{mg}$ of MnO, $0.7 \mathrm{mg}$ of $\mathrm{CoSO} 4 \times 7 \mathrm{H} 2 \mathrm{O}$, $1.0 \mathrm{mg}$ of $\mathrm{KI}, 200 \mathrm{~g}$ of $\mathrm{Na} 2 \mathrm{SeO} 3$, and $380.4 \mathrm{mg}$ corn starch as carrier

${ }^{* *}$ Ingredients per kilogram of diet: $6000 \mathrm{IU}$ of vitamin A, $1500 \mathrm{IU}$ of vitamin D3, $10 \mathrm{IU}$ of vitamin E, $1.5 \mathrm{mg}$ of vitamin K3, $1.0 \mathrm{mg}$ of vitamin B1, $3.0 \mathrm{mg}$ of vitamin B2, $10.0 \mathrm{mg}$ of d-pantothenic acid, $15.0 \mathrm{mg}$ of niacin, $1.0 \mathrm{mg}$ of vitamin B6, 15.0 $\mathrm{g}$ of vitamin $\mathrm{B} 12,250 \mathrm{mg}$ of FeSO 4 × 7H2O, $62.8 \mathrm{mg}$ of CuSO4, $197.4 \mathrm{mg} \mathrm{ZnSO} 4 \times 7 \mathrm{H} 2 \mathrm{O}, 38.8 \mathrm{mg}$ of $\mathrm{MnO}, 0.7 \mathrm{mg}$ of CoSO $4 \times 7 \mathrm{H} 2 \mathrm{O}, 1.0 \mathrm{mg}$ of Kl, $200 \mathrm{~g}$ of $\mathrm{Na} 2 \mathrm{SeO} 3,200 \mu \mathrm{CrPic}$ and $380.4 \mathrm{mg}$ corn starch as carrier

\section{Results and Discussion}

There was no $(P>0.05)$ effect on overall growth performance of pigs fed supplemental CrPic (Table 2). Similar to the present study, Shelton et al. (2003), Kornegay et al. (1997) and Amoikon et al. (1995) reported that supplemental $\mathrm{Cr}(200 \mu \mathrm{g} / \mathrm{kg} \mathrm{Cr}$ picolinate) resulted in no differences between groups for performance parameters when $\mathrm{Cr}$ was added to the pigs' diet. Average daily gain was increased, but ADFI and gain : feed were not affected by $200 \mathrm{ppb} \mathrm{Cr}$ additions to the diet (Page et al., 1993). An improvement in gain : feed ratio but no observed differences for ADG or ADFI were reported by Lindemann et al. (1995). (Figure 1).

Plasma haematological and biochemistry constituents did not differ $(P>0.05)$ by addition of $\mathrm{CrPic}$ 
Table 2 Mean performances $( \pm$ SEM) of pigs fed two diets differing in chromium picolinate concentration

\begin{tabular}{lcccc}
\hline Items & $\mathbf{C}$ & $\mathbf{E}$ (+ CrPic) & SEM & P-value* $^{*}$ \\
\hline Initial weight $(\mathrm{kg})$ & 17.18 & 17.14 & 0.21 & 0.9341 \\
Final weight (kg) & 37.28 & 36.98 & 1.23 & 0.9139 \\
Average daily gain (kg/pig/day) & 0.74 & 0.73 & 0.05 & 0.9375 \\
Average daily intake (kg/pig/day) & 1.64 & 1.71 & 0.10 & 0.7583 \\
Feed efficiency (kg feed: kg gain) & 2.30 & 2.49 & 0.26 & 0.7437
\end{tabular}

${ }^{*}$ Means within a row did not differ significantly at $P<0.05$, C-Control, E- Control + chromium picolinate, CrPic- chromium picolinate

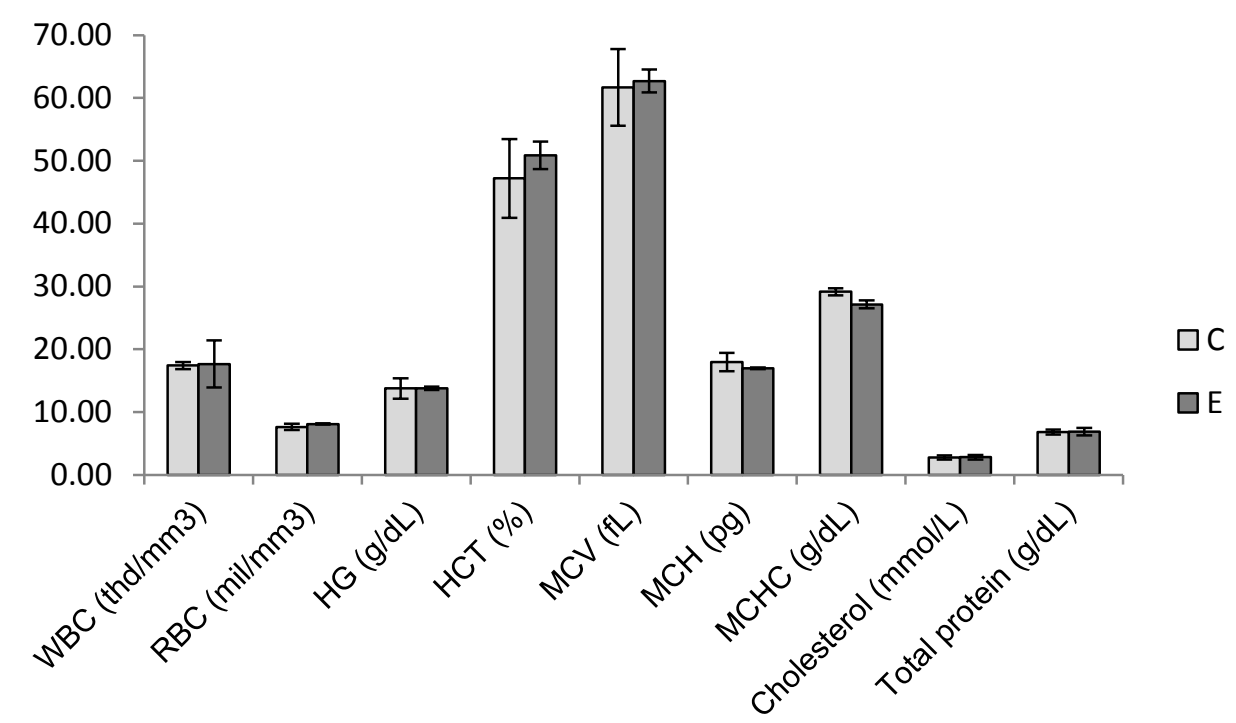

WBC: white blood cells, RBC: red blood cells, HG: haemoglobin, HCT: haematocrit, MCH: mean corpuscular haemoglobin, MCV: mean corpuscular volume, MCHC: mean corpuscular haemoglobin concentration

Figure 1 Haematological and biochemical parameters of pigs fed two diets differing in chromium picolinate concentration at the end of experiment

All pigs from the CrPic supplemented group remained in good health throughout the experimental period. No signs of toxicity were observed. Haematological and biochemical parameters determined in plasma were within normal limits, according Merck manual (2012). The data regarding plasma haematological and biochemical profile agree with other researchers, who showed that $\mathrm{Cr}$ supplementation did not affect the plasma metabolites of pigs (Lien et al., 2005). Amoikon et al. (1995) reported an increase in fasting plasma cholesterol. Other researchers reported a decrease in cholesterol in Cr-supplemented pigs (Page et al., 1993).

The results of the balance study (Table 3) showed that $200 \mathrm{ppb} \mathrm{Cr}$ (III) produced a slight increase of the apparent absorption coefficients for $\mathrm{E}$ group in $\mathrm{N}$ balance. Pigs fed diets supplemented with $\mathrm{Cr}$ excreted an increased $(P<0.05)$ amount of fat but had a decreased $(P<0.05)$ apparent absorption coefficient compared with the pigs from the control group.

Kornegay et al. (1997) showed that $200 \mathrm{ppb} \mathrm{Cr}$ as CrPic had a positive influence on the rate of nitrogen (N) absorption and DM digestibility. Lindemann et al. (1999) considered that $\mathrm{Cr}$ has the potential to increase carcass lean and, in that way, to prevent the negative environmental impact of nitrogen excretion of greater protein intakes. Some researchers have shown that $\mathrm{Cr}$ supplementation in monogastric animals had a beneficial influence on lipid metabolism (Wang et al., 2009). The results of the current study sustain this opinion, as the apparent digestibility coefficient for fat was decreased compared with the control group. 
Table 3 Effect of chromium picolinate supplements on apparent nutrient digestibility

\begin{tabular}{lcccc}
\hline Items & $\mathbf{C}$ & E (+ CrPic) & SEM & P-value $^{*}$ \\
\hline Nitrogen & & & & \\
Ingested (g/day/pig) & 46.27 & 47.91 & 2.03 & 0.6996 \\
Excreted (g/day/pig) & 9.34 & 9.03 & 0.66 & 0.8200 \\
Absorbed (g/day/pig) & 36.93 & 39.42 & 1.47 & 0.4099 \\
Apparent absorption (\%) & 80.27 & 82.41 & 0.66 & 0.1067 \\
& & & & \\
Fat & & & & \\
Ingested (g/day/pig) & 54.91 & 59.30 & 2.41 & 0.4180 \\
Excreted (g/day/pig) & $23.71^{\mathrm{b}}$ & $30.98^{\mathrm{a}}$ & 1.87 & 0.0363 \\
Absorbed (g/day/pig) & 31.20 & 28.32 & 1.31 & 0.3175 \\
Apparent absorption (\%) & $56.96^{\mathrm{b}}$ & $47.66^{\mathrm{a}}$ & 1.98 & 0.0012 \\
& & & &
\end{tabular}

${ }^{*}$ Values with the different superscript in the same raw are statistically different $(P<0.05)$

C-Control, E- Control + chromium picolinate, CrPic- chromium picolinate

The five main cuts, namely ham, loin, shoulder, belly and tenderloin, were considered for proximate (crude protein, crude fat) and cholesterol analysis to determine the influence of CrPic on carcass quality (Figure 2). CP concentrations increased for all anatomical parts belonging to $\mathrm{E}$ group, but for tenderloin and ham, treatment $\mathrm{E}$ differed $(P=0,0342$ for tenderloin and $P=0.0024$ for ham) from treatment $\mathrm{C}$. The opposite tendency was observed for crude fat concentrations in all analysed samples (decreased values for $E$ group), but differences $(P=0.0357$ for belly and $P=0.0305$ for ham) were noticed for belly and ham samples. The values obtained for cholesterol level in $\mathrm{Cr}$-supplemented group samples, were lower than samples from $\mathrm{C}$ group, but only numerically $(P>0.05)$ (Figure 3$)$.

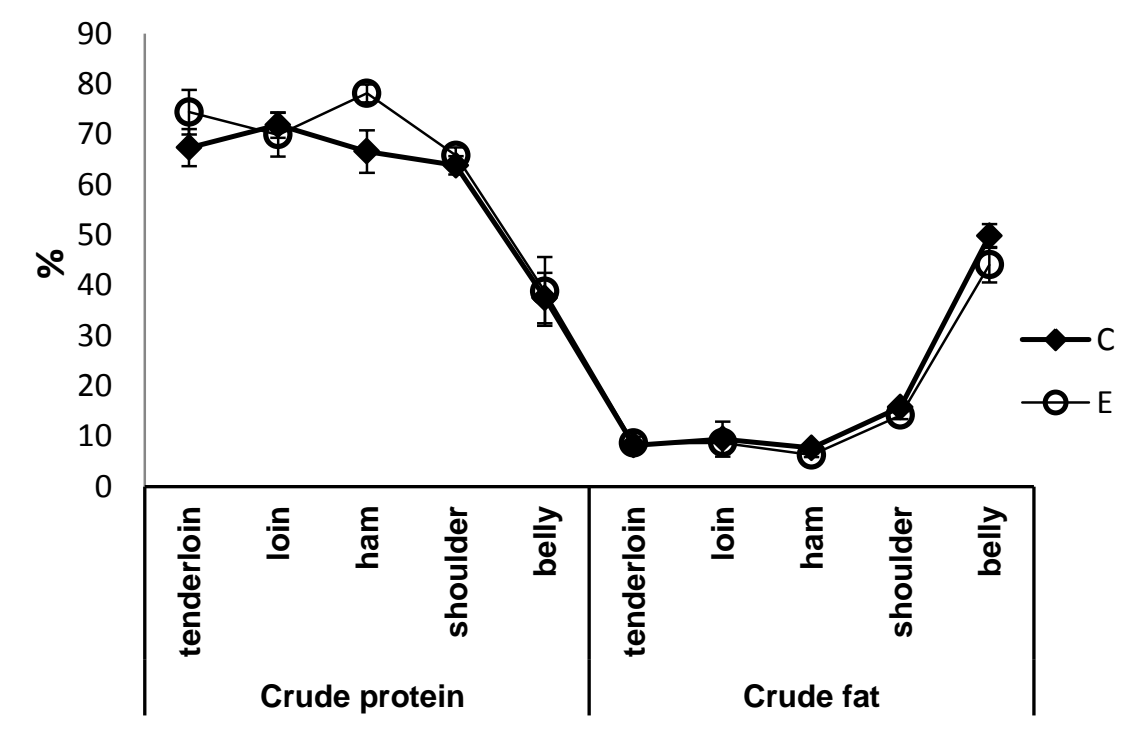

C-Control, E- Control + chromium picolinate

Figure 2 Crude protein and crude fat concentrations in five anatomical parts of pigs fed two diets differing in chromium picolinate concentration 


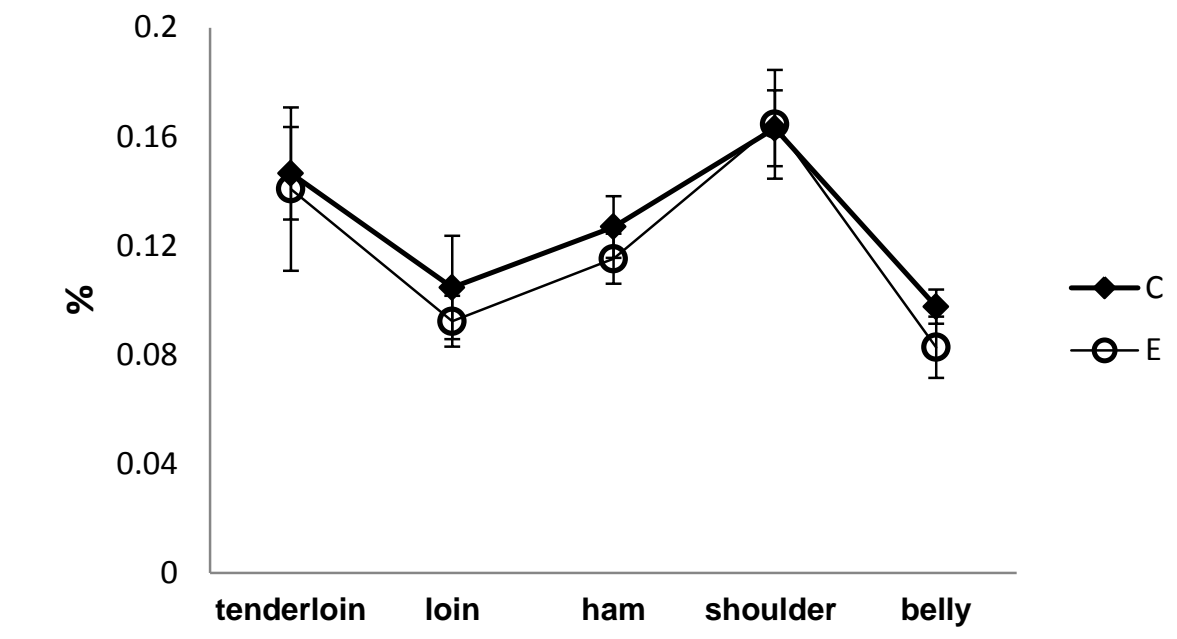

C-Control, E- Control + chromium picolinate

Figure 3 Cholesterol concentrations in five anatomical parts of pigs fed two diets differing in chromium picolinate concentration

Carcass quality was influenced by $\mathrm{Cr}$ supplementation. The positive effect of supplemented $\mathrm{Cr}$ in increasing the proportion of muscle to fat has been reported in several studies (Page et al., 1993; Wang \& $\mathrm{Xu}, 2004)$. A plausible theory is that a low molecular weight $\mathrm{Cr}$ binding protein (chromodulin) is linked to the action of the insulin receptor, glucose entry is increased into adipocytes, lipogenesis is increased and the net fatty acid release decreases (McNamara \& Valdez, 2005). The results of the current study indicate that $\mathrm{Cr}$ as CrPic had no effect on the cholesterol levels of the five anatomical parts. Research studies highlighted the positive effect of $\mathrm{Cr}$ in decreasing the blood level cholesterol (Vincent, 2000), but other researchers did not find any effect of $\mathrm{Cr}$ on lipid metabolism (Rabinowitz et al., 1983).

For fatty acids characterization, the authors considered the anatomical parts with fat content being significantly $(P>0.05)$ lower in $\mathrm{E}$ group compared with $\mathrm{C}$ (Table 4). No significant differences were noticed between groups regarding the quality of fat.

Regarding meat fatty acids composition, the current results agree with findings of other researchers (Jackson et al., 2009), who considered that $\mathrm{Cr}$ supplementation did not influence the fatty acid characteristics, because the profile is a reflection of the dietary fatty acids. A systematic review of eighteen human studies of the effect of $\mathrm{Cr}$ supplementation on lipid profiles showed a statistically heterogeneity of meta-analyses. The conclusion of the study was that there was no beneficial effect of $\mathrm{Cr}$ supplementation on lipid metabolism (Balk et al., 2007). Choi et al. (1998) considered that $\mathrm{Cr}$ increased in vitro lipolytic activity in adipose tissue of pig, without effects on lipogenesis, while Xi et al. (2001) showed that Cr supplements may decrease fat accretion through inhibiting lipogenesis.

Table 5 shows the amino acid composition in tenderloin and ham samples (the only two anatomical parts with significant increased protein concentration compared to $\mathrm{C}$ group). A lack of published data was noticed about the influence of $\mathrm{Cr}$ supplements on amino acid concentrations of pork. In the current study, the experimental group had higher levels $(P<0.05)$ of dispensable, semi-essential and essential amino acids, including glutamic acid, arginine, valine $(P<0.05)$ and serine, tyrosine $(P<0.01)$, in tenderloin and ham. Lysine, cystine, methionine and arginine are the essential amino acids for pigs (Habeanu et al., 2011). In the tenderloin, significantly higher levels $(P<0.05)$ of arginine and lysine, and only arginine for ham, were registered for the experimental group. The sum of essential amino acids increased $(P<0.05)$ compared with $\mathrm{C}$ group, for both types of cuts. $\mathrm{C}$ and $\mathrm{E}$ diets had the same level of amino acids and no differences were reported regarding average daily intake. In this context, it can be considered that the positive effect registered on the amino acid profile of $E$ group is the influence of CrPic supplement.

Amino acids are the basic units of proteins and determine the quality and flavour of the meat (Cai, 2010). Cai et al. (2010) and Conde-Aguilera et al. (2014) reported high contents of glutamic acid, aspartic acid, lysine, leucine and arginine in the longissimus dorsi muscle of pigs, which is similar to the current results. Evans \& Bowman (1992) showed that Cr supplementation in rat diets led to an increased uptake of glucose and amino acids in the skeletal muscle. These findings were attributed to the change in insulin parameters which are $\mathrm{Cr}$ related (Amata, 2013). Lien et al (2001) suggest that $\mathrm{Cr}$ supplementation increases the activity of insulin, which stimulates amino acid transport and protein synthesis in muscle cells. 
Table 4 Fatty acid composition of belly and ham samples

\begin{tabular}{|c|c|c|c|c|c|c|c|c|c|}
\hline \multirow{2}{*}{\multicolumn{2}{|c|}{ Fatty acid (\% of total FAME*) }} & \multicolumn{4}{|c|}{ Belly } & \multicolumn{4}{|c|}{ Ham } \\
\hline & & \multirow{2}{*}{$\begin{array}{c}\text { C } \\
0.15\end{array}$} & \multirow{2}{*}{$\begin{array}{c}E \\
0.14\end{array}$} & \multirow{2}{*}{$\begin{array}{c}\text { SEM } \\
0.004\end{array}$} & \multirow{2}{*}{$\begin{array}{c}\begin{array}{c}\text { P- } \\
\text { value }\end{array} \\
0.207\end{array}$} & \multirow{2}{*}{$\frac{\mathbf{C}}{0.15^{\mathrm{b}}}$} & \multirow{2}{*}{$\begin{array}{c}\mathbf{E} \\
0.22^{\mathrm{a}}\end{array}$} & \multirow{2}{*}{$\begin{array}{c}\text { SEM } \\
0.02\end{array}$} & \multirow{2}{*}{$\begin{array}{c}\begin{array}{c}\text { P- } \\
\text { value }\end{array} \\
0.014\end{array}$} \\
\hline Lauric acid & (C12:0) & & & & & & & & \\
\hline Myristic acid & (C14:0) & 1.94 & 1.82 & 0.05 & 0.247 & 1.76 & 1.96 & 0.07 & 0.127 \\
\hline Pentadecanoic acid & $(\mathrm{C} 15: 0)$ & 0.24 & 0.21 & 0.02 & 0.510 & 0.13 & 0.16 & 0.01 & 0.355 \\
\hline Pentadecenoic acid & $(\mathrm{C} 15: 1)$ & 0.09 & 0.19 & 0.03 & 0.132 & 0.57 & 0.55 & 0.06 & 0.842 \\
\hline Palmitic acid & $(\mathrm{C} 16: 0)$ & 27.40 & 25.98 & 0.43 & 0.195 & 26.71 & 26.73 & 0.32 & 0.951 \\
\hline Palmitoleic acid & $(\mathrm{C} 16: 1)$ & 4.01 & 3.47 & 0.19 & 0.160 & 4.10 & 4.07 & 0.15 & 0.940 \\
\hline Heptadecanoic acid & $(\mathrm{C} 17: 0)$ & 0.35 & 0.38 & 0.04 & 0.790 & 0.40 & 0.40 & 0.04 & 0.929 \\
\hline Heptadecenoic acid & (C17:1) & 0.36 & 0.38 & 0.04 & 0.797 & 0.36 & 0.36 & 0.03 & 0.928 \\
\hline Stearic acid & (C18:0) & 11.90 & 12.54 & 0.38 & 0.448 & 10.47 & 10.21 & 0.30 & 0.715 \\
\hline Oleic acid & (C18:1) & 42.01 & 41.67 & 0.55 & 0.898 & 40.69 & 40.36 & 0.62 & 0.950 \\
\hline Linoleic acid & (C18:2) & 10.11 & 11.37 & 0.41 & 0.130 & 10.62 & 11.77 & 0.42 & 0.181 \\
\hline Linolenic acid & $(C 18: 3 n-3)$ & 0.34 & 0.37 & 0.01 & 0.240 & 0.31 & 0.34 & 0.02 & $>0.99$ \\
\hline Eicosadienoic acid & $(C 20: 2 n-6)$ & 0.53 & 0.53 & 0.02 & 0.963 & 0.51 & 0.44 & 0.02 & 0.155 \\
\hline Eicosatrienoic acid & $(C 20: 3 n-6)$ & 0.34 & 0.35 & 0.01 & 0.843 & 0.37 & 0.36 & 0.02 & 0.844 \\
\hline Eicosatrienoic acid & $(C 20: 3 n-3)$ & 0.04 & 0.02 & 0.01 & 0.821 & 0.20 & 0.18 & 0.02 & 0.298 \\
\hline Arachidonic acid & $(C 20: 4 n-6)$ & 0.30 & 0.52 & 0.06 & 0.080 & 1.66 & 1.40 & 0.15 & 0.432 \\
\hline Docosatetraenoic acid & $(\mathrm{C} 22: 4 n-6)$ & - & - & - & - & 0.28 & 0.25 & 0.02 & 0.272 \\
\hline Other fatty acids & & 0.15 & 0.05 & 0.57 & 0.401 & 0.58 & 0.23 & 0.04 & 0.175 \\
\hline \multicolumn{10}{|l|}{ TOTAL } \\
\hline$\Sigma$ Saturated acids & & 41.72 & 41.06 & 0.57 & 0.602 & 39.61 & 39.72 & 0.53 & 0.931 \\
\hline$\Sigma$ Unsaturated acids & & 58.14 & 58.88 & 0.47 & 0.550 & 59.69 & 60.08 & 0.53 & 0.739 \\
\hline$\Sigma \mathrm{n}-6$ & & 11.28 & 12.77 & 1.53 & 0.104 & 13.45 & 14.23 & 0.51 & 0.488 \\
\hline$\Sigma \mathrm{n}-3$ & & 0.38 & 0.39 & 0.46 & 0.770 & 0.51 & 0.52 & 0.01 & 0.662 \\
\hline Ratio n-6/n-3 & & 30.06 & 32.77 & 0.57 & 0.418 & 26.44 & 27.23 & 0.67 & 0.591 \\
\hline
\end{tabular}

*FAME: fatty acid ester methyl, C-Control, E- Control + chromium picolinate, ${ }^{\text {ab }}$ Values with the different superscript in the same row are statistically different $(P<0.05)$

\section{Conclusions}

The results of the study indicate that $\mathrm{Cr}$ supplements $(200 \mathrm{ppb})$ improve certain aspects of nutrient balance parameters and pork quality. Cr supplementation increased the rate of protein deposition (tenderloin and ham) and reduced the rate of fat deposition (belly and ham). The concentrations of essential amino acids in tenderloin and ham samples of $\mathrm{Cr}$ supplemented group were improved, indicating the potential of using $\mathrm{Cr}$ to develop functional foods. The mechanisms underlying these effects are not fully understood, and more research is necessary to evaluate the consistency of these results. 
Table 5 Amino acid composition in tenderloin and ham samples

\begin{tabular}{lccccccccc}
\hline \multirow{2}{*}{ Amino acids (\% DM) } & \multicolumn{4}{c}{ Tenderloin } & \multicolumn{4}{c}{ Ham } \\
\cline { 2 - 9 } & C & E & SEM & P-value & C & E & SEM & P-value \\
\hline Aspartic acid & 8.30 & 8.95 & 0.18 & 0.0640 & 9.10 & 9.40 & 0.125 & 0.2672 \\
Glutamic acid & $15.59^{\mathrm{b}}$ & $17.15^{\mathrm{a}}$ & 0.34 & 0.0059 & $23.88^{\mathrm{b}}$ & $19.47^{\mathrm{a}}$ & 0.900 & 0.0010 \\
Glycine & 4.28 & 4.63 & 0.11 & 0.1269 & 4.26 & 4.56 & 0.204 & 0.5058 \\
Alanine & $5.35^{\mathrm{b}}$ & $5.80^{\mathrm{a}}$ & 0.11 & 0.0437 & 5.72 & 6.06 & 0.097 & 0.0677 \\
Serine & $4.83^{\mathrm{b}}$ & $5.30^{\mathrm{a}}$ & 0.09 & 0.0475 & $2.63^{\mathrm{b}}$ & $3.48^{\mathrm{a}}$ & 0.164 & 0.0001 \\
Arginine & $7.47^{\mathrm{b}}$ & $8.09^{\mathrm{a}}$ & 0.16 & 0.0422 & $7.45^{\mathrm{b}}$ & $8.14^{\mathrm{a}}$ & 0.159 & 0.0112 \\
Tyrosine & 3.08 & 3.30 & 0.06 & 0.0778 & $3.25^{\mathrm{b}}$ & $3.97^{\mathrm{a}}$ & 0.144 & 0.0004 \\
Cystine & 1.15 & 1.14 & 0.02 & 0.8421 & 0.89 & 0.85 & 0.030 & 0.5005 \\
Threonine & 3.90 & 4.11 & 0.07 & 0.1764 & 4.51 & 4.79 & 0.082 & 0.0829 \\
Valine & 3.17 & 3.42 & 0.09 & 0.1718 & $6.06^{\mathrm{b}}$ & $6.92^{\mathrm{a}}$ & 0.210 & 0.0244 \\
Phenylalanine & 2.50 & 2.55 & 0.06 & 0.7585 & 3.80 & 3.97 & 0.056 & 0.1312 \\
Isoleucine & $4.04^{\mathrm{b}}$ & $4.60^{\mathrm{a}}$ & 0.13 & 0.0273 & 4.43 & 4.56 & 0.065 & 0.3233 \\
Leucine & $7.13^{\mathrm{b}}$ & $7.85^{\mathrm{a}}$ & 0.18 & 0.0381 & 8.05 & 8.43 & 0.119 & 0.1060 \\
Lysine & $6.77^{\mathrm{b}}$ & $7.71^{\mathrm{a}}$ & 0.23 & 0.0298 & 8.02 & 8.02 & 0.096 & 0.9724 \\
Methionine & 1.38 & 1.47 & 0.03 & 0.2050 & 1.58 & 1.63 & 0.079 & 0.7784 \\
Other amino acids & $21.06^{\mathrm{b}}$ & $13.95^{\mathrm{a}}$ & 1.74 & 0.027 & 6.38 & 5.76 & 0.460 & 0.5423 \\
TOTAL & & & & & & & & \\
$\Sigma$ Iispensable amino acids & $33.52^{\mathrm{b}}$ & $36.53^{\mathrm{a}}$ & 0.71 & 0.0175 & $42.94^{\mathrm{b}}$ & $39.48^{\mathrm{a}}$ & 0.662 & $<0.0001$ \\
$\Sigma$ Semi-essential amino acids & $16.53^{\mathrm{b}}$ & $17.83^{\mathrm{a}}$ & 0.33 & 0.0391 & $14.22^{\mathrm{b}}$ & $16.44^{\mathrm{a}}$ & 0.445 & 0.0005 \\
$\Sigma$ Essential amino acids & $28.89^{\mathrm{b}}$ & $31.69^{\mathrm{a}}$ & 0.71 & 0.0351 & $36.45^{\mathrm{b}}$ & $38.32^{\mathrm{a}}$ & 0.251 & 0.0404 \\
& & & & & & & & \\
\hline
\end{tabular}

C-Control, E- Control + chromium picolinate, ${ }^{\text {ab }}$ Values with the different superscript in the same row are statistically different $(P<0.05)$

\section{Acknowledgements}

This work was supported by a grant of the Romanian National Authority for Scientific Research and Innovation, CNCS-UEFISCDI, project number PN-II-RU-TE-2014-4-0997

\section{Authors' Contributions}

AEU and IV performed the design of study, interpretation of data and drafted the manuscript. TDP, MH, GMC, $\mathrm{MR}, \mathrm{MO}$, IV participated at acquisition of data. MH revised the manuscript critically for intellectual content. All authors read and approved the final manuscript.

\section{Conflict of Interest Declaration}

The authors of the manuscript have no conflict of interest to declare

\section{References}

Amata, I.A., 2013. Chromium in livestock nutrition: A review. Glo. Adv. Res. J. Agric. Sci. 2, 289-306.

Amoikon, E.K., Fernandez, J.M., Southern, L.L., Thompson, D.L., Ward, T.L., Olcott, B.M., 1995. Effect of chromium tripicolinate on growth, glucose tolerance, insulin sensitivity, plasma metabolites, and growth hormone in pigs. J. Anim. Sci. 73, 1123-1130. 
Balk, E.M., Tatsioni, A., Lichtenstein, A.H., Lau, J. \& Pittas, A.G., 2007. Effect of chromium supplementation on glucose metabolism and lipids a systematic review of randomized controlled trials. Diabetes Care 30, 2154-2163.

Cai, Z.W., Zhao, X.F., Jiang, X.L., Yao, Y.C., Zhao, C.J., Xu, N.Y. \& Wu, C.X., 2010. Comparison of muscle amino acid and fatty acid composition of castrated and uncastrated male pigs at different slaughter ages. Ital. J. Anim. Sci. 9, 173-178.

Choi, Y.J., Kim, H.G., Cho, J.S., Chung, I.B., Kim, Y.H. \& Han, I.K., 1998. Effects of chromium picolinate on in vitro lipogenesis and lipolysis in adipose tissue and protein synthesis in liver tissue of pigs. Asian-Aus. J. Anim. Sci. 11, 428-433.

Conde-Aguilera, J.A., Cobo-Ortega, C., Mercier, Y., Tesseraud, S., Van Milgen, J., 2014. The amino acid composition of tissue protein is affected by the total sulfur amino acid supply in growing pigs. Animal 8, 401-409.

Evans, G.W., Bowman, T.D., 1992. Chromium picolinate increases membrane fluidity and rate of insulin internalization. J. Inorg. Biochem. 48, 243-250.

Habeanu, M., Hebean, V., Taranu, I., Ropota, M., Lefter, N. \& Marin, D., 2011. Dietary ecologic camelina oil - a beneficial source of $n-3$ PUFA in muscle tissue and health status in finishing pigs. Romanian Biotechnol. Lett. 16, 6564-6571.

Hoffman, L.C., Kritzinger, B. \& Ferreira, A.V., 2005. The effects of region and gender on the fatty acid, amino acid, mineral, myoglobin and collagen contents of impala (Aepyceros melampus) meat. Meat Sci. 69, 551-558.

Jackson, A.R., Powell, S., Johnston, S. L., Matthews, J.O., Bidner, T.D., Valdez, F.R. \& Southern, L.L., 2009. The effect of chromium as chromium propionate on growth performance, carcass traits, meat quality, and the fatty acid profile of fat from pigs fed no supplemented dietary fat, choice white grease, or tallow. J. Anim. Sci. 87, 40324041.

Kornegay, E.T., Wang, Z., Wood, C.M. \& Lindemann, M.D., 1997. Supplemental chromium picolinate influences nitrogen balance, dry matter digestibility, and carcass traits in growing-finishing pigs. J. Anim. Sci. 75, 1319-1323.

Li, Y.S., Zhu, N.H., Niu, P.P., Shi, F.X., Hughes, C.L., Tian, G.X. \& Huang, R.H., 2013. Effects of dietary chromium methionine on growth performance, carcass composition, meat colour and expression of the colour-related gene myoglobin of growing-finishing pigs. Asian-Aus. J.Anim.Sci. 26, 1021-1029.

Lien, T.F., Yang, K.H. \& Lin, K.J., 2005. Effects of chromium propionate supplementation on growth performance, serum traits and immune response in weaned pigs. Asian-Aus. J.Anim.Sci. 18, 403-408.

Lien, T.F., Wu, C.P., Wang, B.J., Shiao, M.S., Shiao, T.Y., Lin, B.H., Lu, J.J. \& Hu, C.Y., 2001. Effects of supplemental levels of chromium picolinate on the growth performance, serum traits, carcass characteristics and lipid metabolism of growing-finishing pigs. Anim. Sci. 72, 289-296.

Lindemann, M.D., 1999. Chromium and swine nutrition. J. Trace Elem. Med. Bio. 12, 149-161.

Lindemann, M.D., Wood, C.M., Harper, A.F., Kornegay, E.T. \& Anderson, R.A., 1995. Dietary chromium picolinate additions improve gain: Feed and carcass characteristics in growing-finishing pigs and increase litter size in reproducing sows. J. Anim. Sci. 73, 457-465.

Matthews, J.O., Guzik, A.C., LeMieux, F.M., Southern, L.L. \& Bidner, T.D., 2005. Effects of chromium propionate on growth, carcass traits, and pork quality of growing-finishing pigs. J. Anim. Sci. 83, 858-862.

McNamara, J.P. \& Valdez, F., 2005. Adipose tissue metabolism and production responses to calcium propionate and chromium propionate. J. Dairy Sci. 88, 2498-2507.

Merck, 2012. Haematological reference ranges. Merck veterinary manual. http://www.merckmanuals.com, retrieved $01 / 03 / 2016$

Millward, D.J., Layman, D.K., Tomé, D. \& Schaafsma, G., 2008. Protein quality assessment: Impact of expanding understanding of protein and amino acid needs for optimal health. Am. J. Clin. Nutr. 87, 1576S-1581S.

Monziols, M., Collewet, G., Bonneau, M., Mariette, F., Davenel, A. \& Kouba, M., 2006. Quantification of muscle, subcutaneous fat and intermuscular fat in pig carcasses and cuts by magnetic resonance imaging. Meat Sci. 72 , 146-154.

Mooney, K.W. \& Cromwell, G.L., 1995. Effects of dietary chromium picolinate supplementation on growth, carcass characteristics, and accretion rates of carcass tissues in growing-finishing swine. J. Anim. Sci. 73, 3351-3357.

Page, T.G., Southern, L.L., Ward, T.L. \& Thompson, D.L., 1993. Effect of chromium picolinate on growth and serum carcass traits of growing-finishing pigs. J. Anim. Sci. 71, 656-662.

Pechova, A. \& Pavlata, L., 2007. Chromium as an essential nutrient: a review. Vet. Med. Czech. 52, 1-18.

Rabinowitz, M.B., Gonick, H.C., Levin, S.R. \& Davidson, M.B., 1983. Effects of chromium and yeast supplements on carbohydrate and lipid metabolism in diabetic men. Diabetes Care 6, 319-327.

Sahin, K., Ozbey, O., Onderci, M., Cikim, G. \& Aysondu, M.H., 2002. Chromium supplementation can alleviate negative effects of heat stress on egg production, egg quality and some serum metabolites of laying Japanese quail. $\mathrm{J}$. Nutr. 132, 1265-1268.

Sales, J. \& Jancík, F., 2011. Effects of dietary chromium supplementation on performance, carcass characteristics, and meat quality of growing-finishing swine: A meta-analysis. J. Anim. Sci. 89, 4054-4067.

Schiemann, R., 1981. Methodische Richtlinien zur Durchführung von Verdauungs-versuchen für die Futterwertschätzung. Arch. Anim. Nutr. 31, 1-19.

Shelton, J.L., Pyne, R.L., Johnston, S.L. \& Bitner, T.D., 2003. Effect of chromium propionate on growth carcass traits, pork quality and plasma metabolites in growing-finishing pigs. J. Anim. Sci. 81, 2515-2524.

Van Heugten, E.V., Spears, J.W., 1997. Immune response and growth of stressed weanling pigs fed diets supplemented with organic or inorganic forms of chromium. J. Anim. Sci. 75, 409-416. 
Varzaru, I., Untea, A.E., Martura, T., Olteanu, M., Panaite, T.D., Schitea, M. \& Van, I., 2013. Development and validation of an RP-HPLC method for methionine, cystine and lysine separation and determination in corn samples. Rev. Chim. Bucharest. 64, 673-679.

Vincent, J.B., 2000. Elucidating a biological role for chromium at a molecular level. Accounts Chem. Res. 33, 503-510.

Wang, M.Q. \& Xu, Z.R., 2004. Effect of chromium nanoparticle on growth performance, carcass characteristics, pork quality and tissue chromium in finishing pigs. Asian-Aus. J. Anim. Sci. 17, 1118-1122.

Wang, M.Q., He, Y.D., Lindemann, M.D. \& Jiang, Z.G., 2009. Efficacy of Cr (III) supplementation on growth, carcass composition, blood metabolites, and endocrine parameters in finishing pigs. Asian-Aus. J. Anim. Sci. 22, 14141419.

Wang, M.Q., Wang, C., Du, Y.J., Li, H., Tao, W.J., Ye, S.S., He Y.D. \& Chen, S.Y., 2014. Effects of chromium-loaded chitosan nanoparticles on growth, carcass characteristics, pork quality, and lipid metabolism in finishing pigs. Livest. Sci. 161, 123-129.

Xi, G., Xu, Z.R., Wu, S.H. \& Chen, S.J., 2001. Effect of chromium picolinate on growth performance, carcass characteristics, serum metabolites and metabolism of lipid in pigs. Asian-Aus. J. Anim. Sci. 14, 258-262. 